\title{
Perspective
}

PERSPECTIVE Actualité en histoire de l'art

\section{2| 2014}

\section{Antiquité/Moyen Âge}

\section{The archaeometry of ancient glassmaking: reconstructing ancient technology and the trade of raw materials}

L'archéométrie de la fabrication du verre ancien : la reconstitution des technologies et du commerce des matières premières

Die Archäometrie der alten Glasherstellung: Rekonstruktion der Techniken und des Rohstoffhandels

L'archeometria della fabbricazione del vetro antico: la ricostruzione delle tecnologie e del commercio delle materie prime

Patrick Degryse, Rebecca B. Scott y Dieter Brems, La arqueometría de la fabricación del vidrio antiguo: reconstitución de las tecnologías y el comercio de las materias primas

\section{Patrick Degryse, Rebecca B. Scott and Dieter Brems}

\section{(apenEdition} Journals

\section{Electronic version}

URL: http://journals.openedition.org/perspective/5617

DOI: 10.4000/perspective.5617

ISSN: 2269-7721

\section{Publisher}

Institut national d'histoire de l'art

\section{Printed version}

Date of publication: 1 December 2014

Number of pages: 224-238

ISSN: 1777-7852

\section{Electronic reference}

Patrick Degryse, Rebecca B. Scott and Dieter Brems, «The archaeometry of ancient glassmaking: reconstructing ancient technology and the trade of raw materials ", Perspective [Online], 2 | 2014, Online since 30 June 2015, connection on 01 October 2020. URL : http://journals.openedition.org/ perspective/5617; DOI : https://doi.org/10.4000/perspective.5617 


\title{
The archaeometry of ancient glassmaking: reconstructing ancient technology and the trade of raw materials
}

\author{
Patrick Degryse, Rebecca B. Scott and Dieter Brems
}

It has long been thought that all Greco-Roman glass originated from the eastern Mediterranean, Syro-Palestine in particular. The scientific examination of archaeological and historical artifacts relies on the assumption that there is a scientifically measurable property that will link an artifact to a particular source. In glass research, no such marker was available. Scientific research in the past decade has developed chemical methods to link glass artifacts to particular source areas. In this way, a new picture of intense GrecoRoman glass trade emerged. While glassmaking sites in the eastern Mediterranean likely produced the first natron glass (made with sand and mineral soda), in early Roman times investments were made in several glassmaking units all over the Empire. In late Roman to early Byzantine times, natron glassmaking once again fell to the glass factories in SyroPalestine and Egypt.

\section{The classics and glass}

Pliny the Elder, writing in the first century AD, describes how glass was first made. "A ship belonging to traders in soda once called here, so the story goes, and they spread out along the shore to make a meal. There were no stones to support their cooking-pots, so they placed lumps of soda from their ship under them. When these became hot and fused with the sand on the beach, streams of an unknown translucent liquid flowed, and this was the origin of glass" (PLINY, NH 36.65; EICHHOLZ, 1962, 151). Although the story is certainly untrue - glass is known from the archaeological record some 2500 years before - Pliny here describes Roman "natron" glass, the predominant glass type from the middle of the first millennium $\mathrm{BC}$ to the eighth century $\mathrm{AD}$, made from sand and a mineral soda called natron. Several locations of suitable glassmaking sand are indicated in Pliny's Natural History: "That part of Syria adjoining Judaea and called Phoenicia [...] This is believed to be the source of the River Belus, which, after a distance of five miles flows into the sea next to the colony of Ptolemais. [...] The beach extends for not more than half a mile, but for many years this area was the sole producer of glass. [...] Sidon was once renowned for its glass factories; glass mirrors, among other things, were invented there. This was the old method of glass manufacture. But now in Italy a white sand, which occurs in the River Volturnus, is found along 6 miles of

\footnotetext{
Patrick Degryse is Professor of Archaeometry at the Department of Earth and Environmental Sciences and director of the Centre for Archaeological Sciences at the KU Leuven (Belgium). Rebecca B. Scott is post-doctoral fellow at the Center for Archaeological Sciences at the KU Leuven. Dieter Brems is currently working as postdoctoral fellow of the Fund for Scientific Research-Flanders (FWO-Vlaanderen). Their main research efforts focus on the use of mineral raw materials in, and organization of, ancient materials production (with special emphasis on glass), using petrographical, mineralogical and (isotope) geochemical techniques.
} 
the seashore between Cumae and Liternum [...] Now sand is blended in a similar way in the provinces of Gaul and Spain" (PLINY, NH 36.65-66; EICHHOLZ, 1962, 149-155).

Pliny also makes reference to the use of soda. In direct reference to glass, he merely says that it was added to the glass batch. He does however say that soda can be found in Media and in Thrace, near Philippi, but that the latter is contaminated (PLINY, NH 31.46; JONES, 1963, 443-445); he also says it can be found in Macedonia

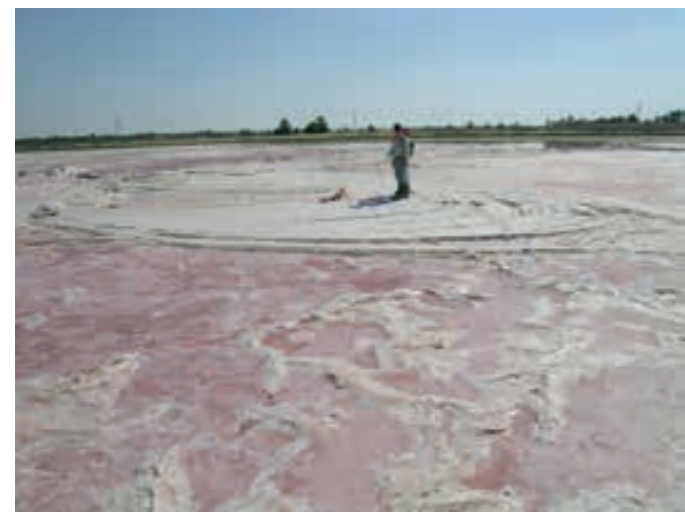

1. Present day deposits of burkeite, trona and halite at Wadi el Natrun (picture taken September 2006). (SAGUí, 2007). He then explains how artificial soda is produced in Egypt in large quantities (PLINY, NH 31.46; JONES, 1963, 445). Natural deposits of soda are well known at the Wadi el Natrun, approximately fifty kilometers northwest of Cairo, Egypt (FREESTONE et al., 2008; fig. 1). None of these soda sources, however, are mentioned in direct relation to glass manufacture (FREESTONE et al., 2008), and their use in the making of glass is unclear.

Yael Gorin-Rosen (GORIN-ROSEN, 2000) explains how the Belus River is today known as the Na'aman Stream, flowing south of Acre, formerly know as Ptolemais. Josephus, writing in the first century $\mathrm{AD}$, highlights the availability of glassmaking sand in the region around Ptolemais, but he does not specify whether glass is actually being manufactured there (JOSEPHUS, THACKERAY, 1927, book 2, chapter 10, section 2). Although there is evidence of glass production in the Acre region, the exact dates of the sites are unknown, i.e. Roman or later (GORIN-ROSEN, 2000).

Strabo also mentions the location of glassmaking sands in his Geography, book 16, again suggesting Syro-Palestine, and Ptolemais in particular, as the source (STRABO, JonES, 1932, book XVI, chapter 2.25). Three classical authors refer to the use of sand from the region of the Belus River. They all tend to suggest, however, that the sand was collected in this region, while the actual process of glassmaking occurred elsewhere. Additionally, several Roman authors and poets mention the production of glass, but few mention locations of the raw materials; most focus on the technological developments such as blowing or recycling glass (STERN, 1999). The question of glass manufacture in the Roman Empire is further complicated by more recent authors, who confuse the manufacture of raw glass with the secondary production of glass vessels, suggesting that glass was at one point produced in almost every area of the empire (STEVENSON, 1914). From the historical texts it can be deduced that primary "raw" glass was probably produced in Syro-Palestine, Egypt, Italy, Gaul, Spain and India, although the method of production may have varied in these locations.

\section{The archaeological evidence}

The archaeological evidence for the production of primary glass (i.e. fused from raw materials into a glass which is then broken into chunks and transported to workshops across the empire for shaping; fig. 2) in the Roman period is limited. Excavations have revealed that, during the fourth to eighth centuries, large quantities of natron glass were made in a limited number of "primary" centers in Egypt and Syro-Palestine (BRILL, 1988, 


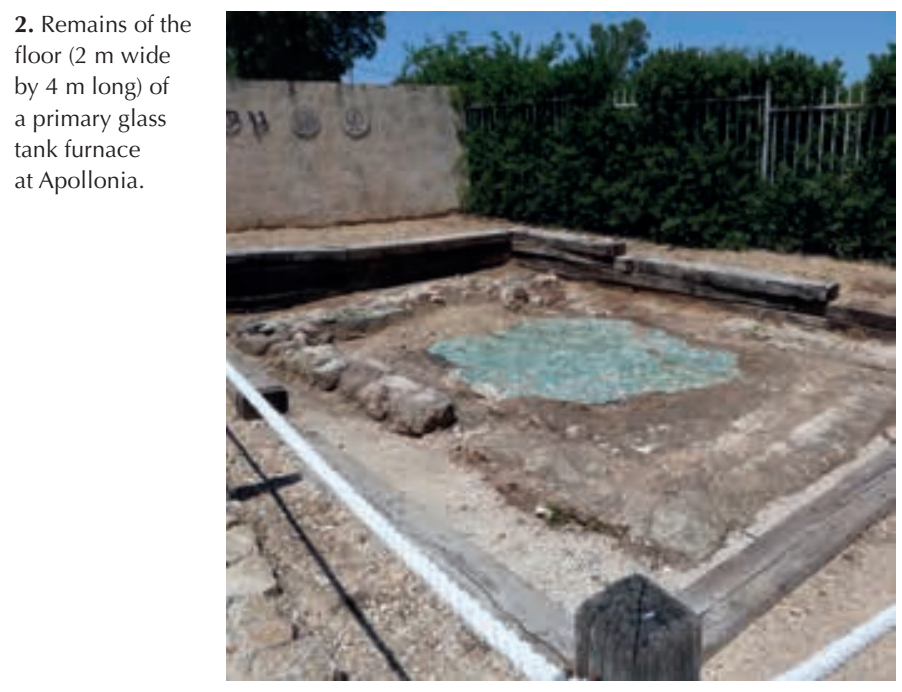

1999; FREESTONE et al., 2000; NENNA et al., 2000; PICON, VICHY, 2003). For example, excavations at Bet Eli'ezer, Israel, revealed the remains of seventeen rectangular furnaces dating to the eighth century AD (FREESTONE et al., 2000; GORIN-ROSEN, 2000), while excavations at Apollonia, Israel, revealed the presence of four furnaces, similar in style to those found at Bet Eli'ezer, dating to the sixth-seventh centuries AD (PERKINS, 1951; GORIN-ROSEN, 2000; TAL et al., 2004; FREESTONE et al., 2008). More recently, evidence of primary and secondary production has been found at the site of Horbat Biz'a, approximately seven kilometers east of Bet Eli‘ezer, al-

though remains of the primary glass furnace itself have not yet been found (GORIN-ROSEN, 2012). Glass furnaces were discovered on the shores of Lake Maryut, near Alexandria, Egypt, dating from the Imperial period to the eighth century AD (NENNA et al., 2000), and Roman glass furnaces of a first-second century AD date have been discovered in Egypt, at Wadi Natrun (NENNA et al., 2000; NENNA, 2007, 2003). However, these are of a different form to the later tank furnaces excavated in Palestine (NENNA et al., 2000; FREESTONE, 2005; NENNA, 2007). The tank furnaces of Israel were extremely large, producing roughly eight to nine tons of glass per firing (FREESTONE et al., 2000; GORIN-ROSEN, 2000), but little further archaeological evidence of primary glass production in the first-fifth centuries has yet been found (PAYNTER, 2006). The furnace locations that have been found are situated either near the favored sand sources, such as the mouth of the Belus River, or close to the alkali sources, such as the Wadi Natrun in Egypt (FREESTONE et al., 2000; NENNA et al., 2000). This corroborates historical sources, which claim that glass was produced using the "old" method in Syro-Palestine and Egypt. As yet, however, little to no evidence of primary glass factories has been found in the other regions mentioned for the earlier Roman period. Six glass factories from the late Imperial period (ca. fourth century) have been suggested at Hambach, Germany (WEDEPOHL, BAUMANN, 2000; WedePOHL et al., 2011), as well as a second-century AD tank furnace in a Roman military camp at Bonn (WEDEPOHL et al., 2011).

Secondary glass workshops were, however, more prolific across the empire. For example, historic records mention glass workers being shipped from Syria and Judea to Rome (FLEMING, SWANN, 1999). Excavations at Pompeii revealed the presence of glass workshops which, based on the eruption of Vesuvius, must date to before AD 79 (DE FRANCESCO et al., 2010). Secondary production of glass dating from Imperial to early Byzantine times has also been found at Sagalassos, Turkey (DEGRYSE et al., 2006). The archaeological evidence for glassmaking in the western part of the empire is scarce, but, by the late Roman period, glasshouses where vessels or window glass were fabricated were well established across this region (FOSTER, JACKSON, 2010). The Roman glass workshops of Western Europe are far more common and often better documented than those of the eastern Mediterranean (STERN, 2002), but even without the secondary 
workshops, there is strong evidence for glass production and trade. For example, Roman shipwrecks such as the Embiez or the Iulia Felix have been found carrying cargos of raw glass and glass cullet, broken glass shards collected specifically for recycling (SILVESTRI, 2008). Shipwrecks along the coast of Israel have also been found carrying raw chunk glass, indicating that trade by sea existed (GORIN-ROSEN, 2000). Although cargoes of Roman glass are relatively uncommon, enough shipwrecks have been found to confirm that significant long-distance, seaborne transport existed and that it was not confined to the more expensive, colored or engraved glasses (GIBBINS, 1991). It has been argued that most long-distance trade in the Roman world was related to the provisioning of the armies (SILVESTRI et al., 2006), but it has also been suggested that the formation of the empire and the pacification of the Mediterranean basin in the time of Augustus created a new world market (WEST, 1932), which would have allowed an increase in all types of commercial activity. This, coupled with the invention of glassblowing in the first century, made glass a widespread and commercially available product. Glass finds and references in historical documents reveal that glass was exported to many different areas of the empire, often in large quantities (THORLEY, 1969). "The discovery that molten glass could be blown was nothing less than revolutionary. It was closely related to the equally momentous discovery that broken glass artifacts could be totally remelted, a breakthrough that kindled a literary response in the Flavian period (69-96) equal only to the excitement of Augustan poets about glassblowing" (STERN, 1999, p. 450).

All this archaeological evidence has led to the creation of two main models for glass production in the Roman Empire: local versus centralized. The early models of glass production were based on ideas about the structure of the ceramics industry (FREESTONE, 2005); in other words, it was hoped that the trade in glass vessels, like that of ceramic objects, could be mapped based on the idea that a particular form or typology had a similar composition or came from a specific workshop. This idea posited that a workshop would produce glass of a constant composition which would distinguish it from the glass made in another workshop (FREESTONE, 2005). Each workshop would, in short, produce glass using the raw materials locally available. This "local" model, similar to the medieval model of glass production, would result in a large number of chemically distinct glasses being produced (PAYNTER, 2006). The second model, based on the archaeological evidence of surviving furnace sites (also of a later date than the Roman period), suggests that the glass was made in a small number of primary production centers, and that the raw glass was then shipped to workshops all across the empire for shaping (FREESTONE, 2005). This idea suggests that each primary factory could supply a large number of workshops, and that many different workshops could essentially produce a variety of different items from the same composition of glass. Likewise, a single workshop could receive glass from a number of primary factories (FREESTONE, 2005). This second model would therefore result in only a few chemically distinct groups (PAYNTER, 2006). A third model, wherein a small number of large primary glass factories are active but exceptional local primary glass making centers also exist throughout the empire, is of course also possible.

Although the local model does have supporters and several secondary workshops have been found, the evidence for the production of raw glass outside of the Near East in the early Roman period is still largely illusive. The more favored model suggests that a small number of large primary factories were operating in the Near East, transporting raw glass across the Empire for working at secondary locations. 


\section{What is natron glass, actually?}

Glass is made from a combination of network formers, modifiers and stabilizers. Silica $\left(\mathrm{SiO}_{2}\right)$ is the most common network former in ancient glasses. The silicon atom is bonded to oxygen atoms, and these oxygen atoms are able to link to further silicon atoms, thereby forming a network. In pure silica, this network is often crystalline in structure, but, if properly heated and cooled, the atoms rearrange into a random, non-crystalline network. Producing pure silica glass, however, requires temperatures in excess of $1700^{\circ} \mathrm{C}$ (SHelby, [1997] 2005). This was beyond the capabilities of ancient glassmaking technology. In order to reduce the melting temperature of the silica a fluxing agent is needed, in the form of either soda $\left(\mathrm{Na}_{2} \mathrm{O}\right)$ or potash $\left(\mathrm{K}_{2} \mathrm{O}\right)$. These network modifiers reduce the melting temperature to less than $1000^{\circ} \mathrm{C}$ (SHeLBY, [1997] 2005). The network modifiers disrupt the continuity of the glass network as some of the oxygen atoms bond with the alkali (sodium or potassium). Although the most common fluxes in antiquity were the alkali oxides, others such as lead oxide ( $\mathrm{PbO})$ can also be used to weaken the network and lower the melting temperature. A glass made from only silica and soda would be unstable and susceptible to damage from water, and a stabilizer like lime (CaO) or lead (PbO) is therefore also needed (HODGES, [1964] 1981). However, while too little stabilizer will give the glass poor chemical durability, too much stabilizer will make the glass prone to devitrification. In this case a small amount of alumina $\left(\mathrm{Al}_{2} \mathrm{O}_{3}\right)$ or magnesia $(\mathrm{MgO})$ is beneficial to help prevent devitrification (HARES, 1984).

The glass manufactured during the Greco-Roman period was all soda-lime-silica in composition, the majority of these being made from a mixture of silica sand and mineral soda (natron). This type of glass was made between the early first millennium BC and the ninth century $\mathrm{AD}$ and is characterized by its low magnesium and low potassium values, which cause it to be referred to as LMLK glass (SAYRE, SMITH, 1961; HENDERSON, 1985; FREESTONE, 2006; WEDEPOHL et al., 2011). It can be differentiated from other types of soda-lime-silica glass, which use plant ash as the main flux ingredient and are often referred to as HMHK glasses due to their high magnesium and high potassium contents. A Roman "natron" glass can therefore be recognized by concentrations of magnesia and potash of less than $1.5 \%$.

Suitable glassmaking sands may be difficult to find, as they need to be high in silica and relatively free of impurities. They should also be relatively calcareous (high in lime), or extra lime must be added to the glass batch (SILVESTRI et al., 2006). Certain beach sands, containing lime in the form of crushed shells, are thought to be particularly suited to the purposes of making natron glass. The popularity of colorless glass in the Roman period would have made low-iron, high purity sand essential for the glass industry (JACKSON, 2005). Most of the suitable glassmaking sands are thought to be found in the eastern Mediterranean region. These typically contain around 9\% lime, 3-5\% alumina and less than $1 \%$ magnesia (e.g. AERTS et al., 2000).

The soda used in Roman glass was a mineral form known as natron. The term natron is used here to describe polyphase evaporitic lake deposits that are rich in sodium carbonates (SHORTLAND et al., 2006). Most of the carbonate is in the form of the mineral trona; however, the natron deposits are hardly ever pure carbonates and usually also contain significant amounts of chlorides and/or sulfates. These are highly undesirable because of their limited reaction with silica at the temperatures achieved in the traditional glassmaking furnaces (GORIN-ROSEN, 2000; FREESTONE, 2006). Nevertheless, virtually all Roman glass contains $0.5-1.2 \%$ chlorine $\left(\mathrm{Cl}^{-}\right)$and $0.2-0.5 \%$ sulfate $\left(\mathrm{SO}_{4}{ }^{2-} ;\right.$ BREMS, 2012$)$. 
As noted, glasses made purely from soda and silica are unstable and susceptible to damage from water, thereby requiring the use of a stabilizer (HODGES, 1981). Roman glasses usually contain between 5 and $10 \%$ lime. The major source of lime in these glasses would have been calcium carbonate, which was either added deliberately to the glass batch, as an independent component, or accidentally included, as particles of shell or limestone in the sand (FREESTONE, 2006).

\section{Glass provenancing}

In order to clarify questions over the structure of the glass industry in the Roman period, it is essential to provenance the origin of this glass and its raw materials. This information can then be used in conjunction with archaeological glass assemblages to develop and interpret patterns of trade and use within the Roman period. In its wider context, this information can also help to shed light on the cultural interactions necessary in order to assess the economic impact of the Roman glass industry. The idea that an artifact can be matched to its geological source location has often been used to form the basis of many archaeological theories relating to the migrations of peoples, as well as to social interactions and exchanges (PILlAY, 2001). The determination of the provenance of an object relies on the assumption that there is a measurable scientific property linking an artifact to a particular source or production location. In the case of glass, provenance is used to refer to the origin of the raw materials and/or the place of making of the glass as a material. This is in contrast to the art world's use of the term "provenance," which often refers to the history of the artifact (WILSON, POLLARD, 2001). In theory, the materials used in the manufacture of the glass are matched to the correct geographical source location. This relies on being able to identify the correct signature of the raw material and on the supposition that this signature is inherent to the geological source from which it originated; that the geological signature is not transformed physically or chemically during the manufacturing process (IXER, 2003); and that each raw material has an individual geological signature. Sand sourced from Italy, for example, will have a different signature from sand sourced from Israel. The glass manufacturing and working processes can also leave a signature in the finished product; for instance, glass can be contaminated by the crucible material (JACKSON et al., 2003). Since the chemical properties of an object are seen as characteristic of the raw material source, the composition of the artifact is effectively a "chemical fingerprint" (WILSON, POLLARD, 2001).

In other words, the composition of the different glass samples is analyzed and compared in order to determine whether distinct compositional groups can be identified. Once one or several groups have been established, their composition can be compared to that of specific raw materials from specific sources. The latter part, however, presupposes knowledge of all the characteristics of all the possible sources of a particular raw material, which is rarely the case (HARDING et al., 2004). Since homogeneity between sources can make provenancing difficult, the technique will only ever confirm that an item did not come from a location.

The provenancing of glass, a complex material, is further complicated by the relationship between the raw materials and the finished product. During glass melting, many characteristics of the raw materials, such as mineralogy, grain size and shape, are lost, leaving only bulk chemical data (BREMS, 2012). Roman vessel glass from the first to fifth centuries $\mathrm{AD}$ shows a fairly uniform chemical composition irrespective of the temporal or geographical 
origin of the material (AERTS et al., 2000), especially in its major element composition (WEDEPOHL, BAUMANN, 2000). As analysis reveals, assemblages consisting of vessels of different forms believed to have been produced in different locations are generally indistinguishable compositionally (BAXTER, COOL, JACKSON, 2005). Likewise, the exact provenance of basic utilitarian vessel forms, whose specific origins are rarely identified, is often difficult to determine (GIBBINS, 1991). Supporters of both local and centralized production models have attempted to explain this phenomenon. While those in favor of the local production model claim that the compositional consistency is due either to the use of similar, strictly controlled recipes and production techniques or to the reuse of glass in the form of cullet (BAXTER, COOL, JACKSON, 2005), supporters of the centralized production model attribute compositional homogeneity to the use of raw materials from a limited number of locations.

Provenancing Roman natron glass by retracing its chemical fingerprint presupposes that glass was produced in discrete centers using standardized raw materials and manufacturing techniques. It assumes, moreover, that the signature of each glassmaking centre is individual (JACKSON, 2012). The major elemental signature of Roman natron glass is fairly homogeneous. Manufacturing raw glass from a relatively pure silica source with only minor/ trace level impurities and natron (also low in impurities) is likely to produce a homogeneous signature (JACKSON, 2012). The same result, however, could also be due to the practice of recycling (Degryse et al., 2006; Degryse, ShortLAND, 2009). Something more than just the bulk chemical data of the glasses is therefore needed to enable successful provenancing.

Several attempts have been made using a variety of techniques, including trace element analysis and isotopic signatures (WEDEPOHL, BAUMANN, 2000; FREESTONE et al., 2003; HENDERSON et al., 2005; SHORTLAND et al., 2007; DEGRYSE, SCHNEIDER, 2008; DEGRYSE, SHORTLAND, 2009). In particular, strontium (Sr) and neodymium (Nd) isotopic signatures have been used to make the case that the majority of the Roman glass found in Europe came from the eastern Mediterranean region (FREESTONE et al., forthcoming). Isotopic analysis and trace element analysis are promising as tracers for the raw materials used in glass because they reflect variations found around the Mediterranean Sea as a result of differing geological environments (BREMS, 2012). The strontium content and isotopic signature of ancient glass is a good provenance indicator for the lime used in its manufacture. The neodymium in Roman natron glass originates from the non-quartz minerals in the sand's raw material, and its isotopic composition is an indication of the source of the silica. The element boron (B) is used as a tracer for provenancing the flux source used in ancient natron glassmaking. It enters ancient glass mainly through the mineral flux used, but the sand source also contributes to the total amount of boron in the glass (DEVULDER et al., 2013, 2014) - a fact that complicates efforts to determinate the provenance of the flux.

The chemical and isotopic analysis of the glass can, therefore, provide information on the origin of the raw materials used to produce the glass. This, in conjunction with a comparison of the compositional data between archaeological sites, can potentially reveal patterns in production and trade (SCHIBILLE, 2011). In order to fully understand glass manufacture in the Greco-Roman world, and in the absence of identifiable primary glass production locations, a structured analysis of glass must comprise contextual, chronological, typological and technological evidence from a wide group of assemblages (BAXTER, COOL, JACKSON, 2005).

These multiple angles fundamentally lead to two methods of provenance determination: the first compares the composition of the unknown samples with the composition of 
known material in order to narrow down the potential source origins; the second uses the fundamental geological properties of the artifact to predict a potential origin in the absence of comparative material (FREESTONE et al., forthcoming). The former method relies on existing chemical and isotopic data collected from various Roman glass assemblages, such as the composition of glass collected from primary furnaces or small-scale production from York, England (JACKSON et al., 2003; BINGHAM, JACKSON, 2008), or evidence from detailed studies undertaken on fourth-fifth century HIMT glass and fourth-eighth century Levantine glass (FreEstOne, 2001; FreEstone et al., 2002). The second method utilizes isotopic studies, particularly of strontium and neodymium, to infer the likely locations of glassmaking sands and therefore the location of the primary furnaces in which raw glass was made (DEGRYSE, SCHNEIDER, 2008). It should be remembered that "to understand how glass can be related back to the furnaces in which it was made, the origins of all the components in the glass must be understood" (FREESTONE, 2005, 008.1.3).

\section{The raw materials of Roman glassmaking}

The European Research Council-funded ARCHGLASS project focused in particular on investigating the occurrence of primary production centers of raw glass outside those known from archaeological excavation in Syro-Palestine and Egypt. The western Mediterranean area, including the regions of Italy, Gaul, Spain (regions described by ancient authors as primary glass producers) and North Africa were surveyed for the occurrence of suitable glass raw materials, and analytical techniques using isotope geochemistry were further developed to compare the chemical signatures of possible raw materials to Roman raw glass and objects from museums and archaeological contexts. This reconstruction of the primary origin of Greco-Roman glass refers to broad geological/geographical regions where glass was (likely) made, rather than to individual sites. ${ }^{1}$

The geological survey for suitable sand resources in the Greco-Roman world covered an area from the Portuguese-Spanish border to the Balkans, included parts of Greece, Turkey and Israel, and comprised samples from Egypt to Tunisia (BREMS et al., 2012a, 2012b). The composition of hypothetical glasses made from these modern (beach) sands was calculated, and a series of glass melting experiments were performed to reproduce Roman natron glass. The results of our survey, calculations and experiments showed that suitable glassmaking sands are relatively rare (fig. 3). Six limited areas outside the eastern Mediterranean could be defined where suitable sand raw materials would have been available to the Roman glassmaker. Beach sands from the Basilicata region and the Apulia region in Southeast Italy would produce glass with properties close to Roman glass, but with a typical low alumina content. Sands from the Tuscany region in western Italy are also suited for Roman glass production but would require the addition of extra lime. Beach sands near the mouth of the Guadiana River in the Huelva province of southwestern Spain, in the Murcia region in southeastern Spain and from the Bay of Hyères in southern France (Provence) are all very rich in silica and, with the addition of extra lime, would produce glass with a typical Roman composition. These results do not of course prove that there was a Roman primary glass production industry in the western Mediterranean but demonstrate that the suggested regions are the most likely suppliers of silica raw materials in this area.

Strontium and neodymium isotopic signatures of the sands sampled were measured to compare the composition of Roman natron glass to all known possible sand raw materials. 


\section{Map of the western Mediterranean showing the areas where suitable sand raw materials occur: 1- Basilicata; 2- Apulia; 3- Tuscany; 4A- Huelva; 4B- Murcia; 4C- Provence.}

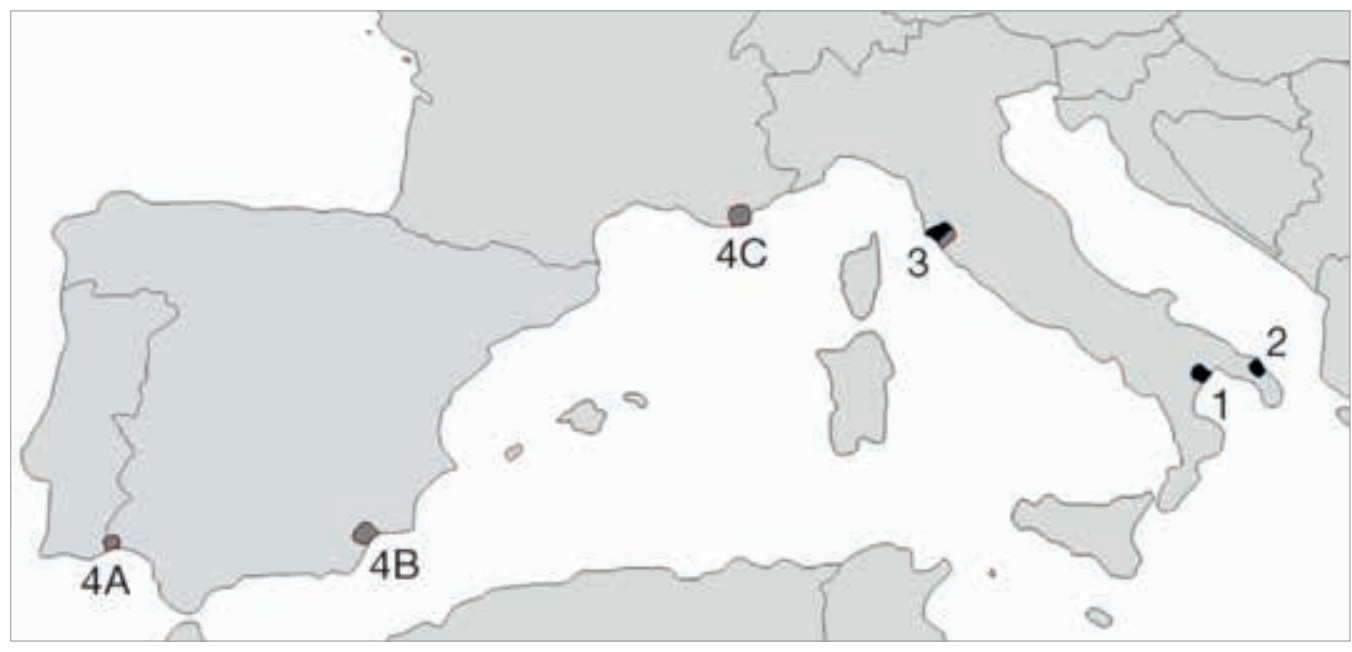

The eastern Mediterranean beach sands used in the glass factories excavated in SyroPalestine were sampled by Robert H. Brill in the 1960s (BRILL, 1999) and analyzed by Patrick Degryse and Jens Schneider (DEGRYSE, SCHNEIDER, 2008) and Dieter Brems and his collaborators (BREMS et al., 2012a). They show neodymium isotopic signatures between -1.0 and $-5 \varepsilon_{\mathrm{Nd}}$ (a standardized notation comparing the measured value to an internationally recognized standard value). Primary glass made using Israeli coastal sand, from the factories at Bet Eli'ezer and Apollonia that were active between the sixth and eighth century AD (BRILL, 1999), produces raw glass with an isotopic signature between -4.1 and $-5.1 \varepsilon_{\mathrm{Nd}}$. Ian Freestone and his collaborators (FREESTONE et al., forthcoming) earlier reported values for Bet Eli'ezer, Apollonia and (likely Egyptian) HIMT primary glass between -4.0 and $-6.0 \varepsilon_{\mathrm{Nd}}$.

Suitable glassmaking sands from Spain, France and the western part of Italy all have relatively low values with neodymium isotopic signatures between - 12.0 and $-7.0 \varepsilon_{\mathrm{Nd}}$ (BREMS et al., 2013a, 2013b; fig. 4). Glass produced from these could be readily distinguished from glass from the known primary production sites in Egypt and Syro-Palestine. Two good sand

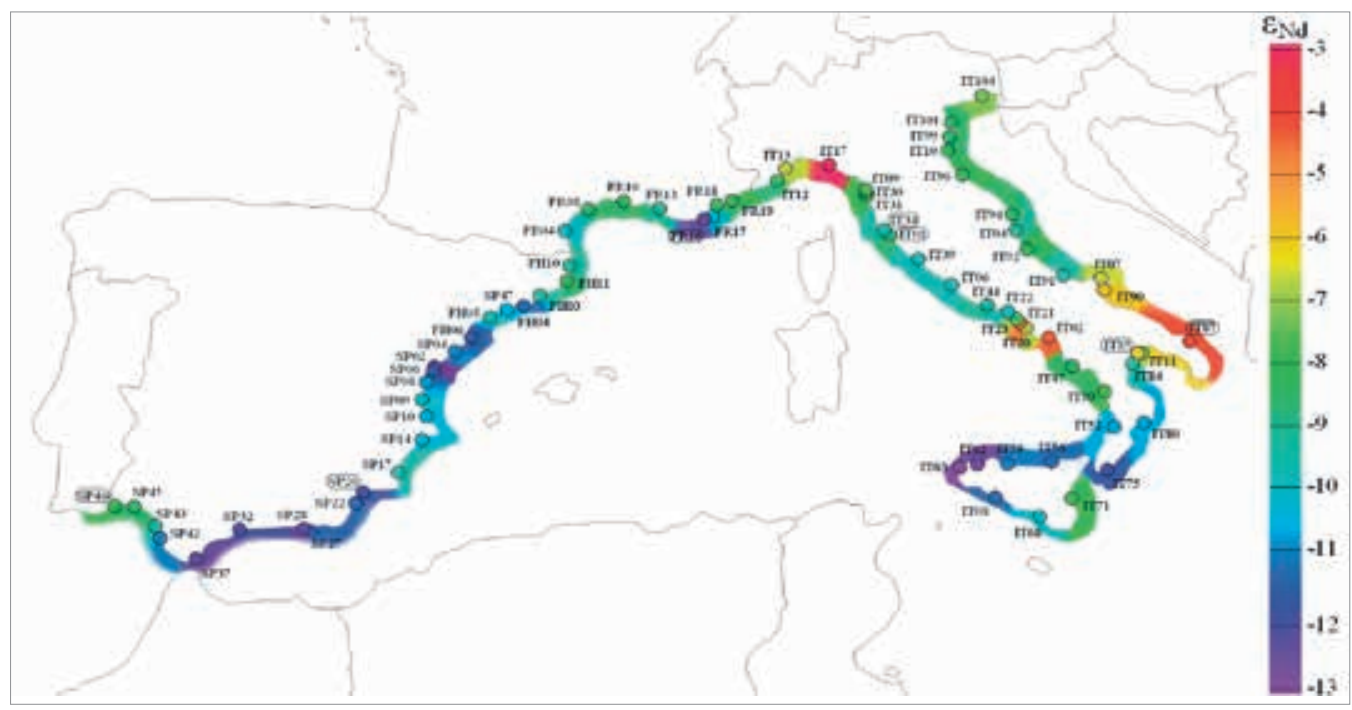


sources in the Basilicata and Apulia Regions of southeastern Italy, however, have $\varepsilon_{\mathrm{Nd}}$ values higher than - $6 \varepsilon_{\mathrm{Nd}^{\prime}}$ which may coincide with signatures of sand and glass with an eastern Mediterranean origin. The Italian sands, though, are much lower in alumina content and show a different trace element signature than the eastern Mediterranean sands analyzed.

A neodymium isotopic signature of ancient glass with $\varepsilon_{\mathrm{Nd}}$ values lower than -7 therefore seems to be a justified cutoff for the primary origin of glass not lying in the eastern Mediterranean. Glass with $\varepsilon_{\mathrm{Nd}}$ values higher than -7.0 and with elevated alumina and/or zirconium and titanium content has a primary origin in the eastern Mediterranean. Glass with $\varepsilon_{\mathrm{Nd}}$ values higher than -6.0 and a low alumina content seem to originate from the Italian peninsula, or a yet unknown source in northern Africa. A special sand that needs to be mentioned is a single sample that was taken near Alexandria. It is as such unsuitable for making a Roman compositional type glass, but it is a very pure sand that could not be distinguished from sands from Apulia and Basilicata using the provenance indicators here defined. The combined use of neodymium isotopic signatures and elemental chemical analysis makes it possible to distinguish between the different possible sources of suitable sand raw materials in all the regions under investigation, as well as the primary origin of glass made from these, but more work is needed to construct an extensive database of Syro-Palestinian to north African sands. ${ }^{2}$

\section{Reconstructing the Roman glass economy}

Looking at the analytical dataset of the ARCHGLASS project (DEGRYSE, 2014; fig. 5), over $60 \%$ of the glass has a chemical and isotopic composition indicative of a primary origin in the eastern Mediterranean, mainly Syro-Palestine. ${ }^{3}$ This glass, naturally colored as well as colorless or strong colored (non-translucent, opaque glass with a strong color, usually pre-Roman in age), is found on all sites studied and occurs over the entire time period studied, from the middle of the first millennium $\mathrm{BC}$ to the ninth century AD. About a third of these samples appear, on the basis of their trace element content, to be recycled glass. ${ }^{4}$

Significantly, geochemical characteristics for around $20 \%$ of the glass assemblage show a primary origin not in Syro-Palestine or Egypt but possibly in the heel of Italy or in an unknown (African) source.

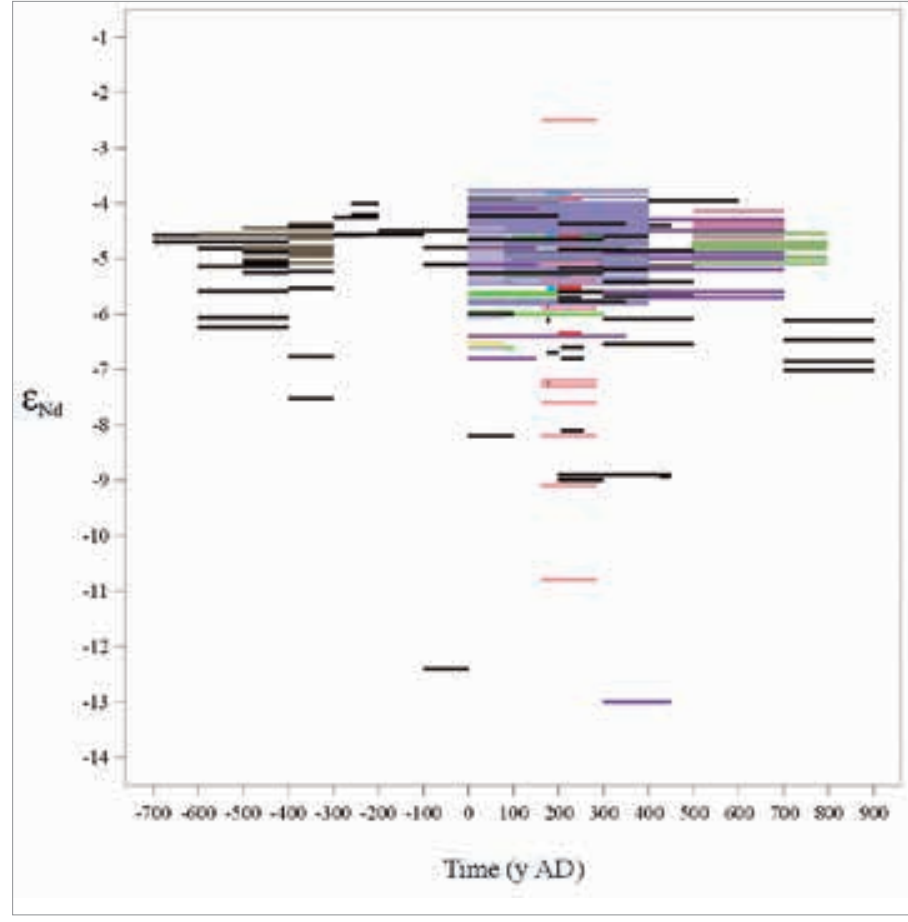

5. Representation of the occurrence of $\varepsilon_{\mathrm{Nd}}$ signatures through time for the full dataset of natron glass analyzed within the ARCHGLASS project (DEGRYSE, 2014). Sample chronology was determined by stratigraphical association. 
Similar samples can be found on many sites all over the sampling area, but most come from the Embiez and Iulia Felix shipwrecks (GANIO et al., 2012a, 2012b). Almost all of this glass is colorless (mostly antimony [Sb] decolored), can be dated between the first and the fourth centuries $\mathrm{AD}$, and has a low lead $(\mathrm{Pb})$ content, showing no indication of recycling or mixing. Interestingly, Daniela Rosenow and Thilo Rehren (Rosenow, REHREN, 2014) used the predominance of first- to second-century antimony- decolored glass at ancient Bubastis (northern Egypt) to suggest a close primary origin of this glass in Egypt. An exceptional group of antimony-decolored glass has an extremely high lead content of several thousand parts per million, likely related to the antimony mineral used in its manufacture. A group of strong colored (mainly black) glass originating in Carthage and dated to the fourth or fifth century BC is the earliest glass of this primary origin so far recognized.

Around $5 \%$ of the glass assemblage studied shows a composition indicative of a primary origin in the western Mediterranean. These glasses are all naturally colored or colorless, and come from all over the sampling area. They are mainly dated between the first century $\mathrm{AD}$ and the first half of the fifth century $\mathrm{AD}$, though some material can be dated as early as the fourth century BC. A small part of the dataset could not be assigned to a specific primary origin, as it had an intermediate composition between all known sources. Most of these samples had a chemical composition suggestive of recycling. Overall, around a quarter of the total glass dataset were samples with elevated trace element contents consistent with recycling. While this shows that recycled glass comprises much of the dataset, this figure is still rather limited.

All natron glass analyzed proved to be very homogenous in boron isotopic composition (DEVULDER et al., 2014; fig. 6), and no significant differences were observed between glasses from different regions or different time periods. This may suggest that, through time and space, one source of flux was used, or multiple sources with a similar boron isotopic composition. The boron isotopic composition of the natron glass studied was very similar to that of several natron sources identified in North Africa (taking into account a contribution from the sand source used). Next to the known occurrence of natron in Wadi el Natrun and al Barnuj, suggested earlier as major sources for natron in ancient glassmaking, the recent

6. Boron isotopic

composition of ancient natron glass analyzed within the ARCHGLASS project (DEGRYSE, 2014), compared to possible natron sources.

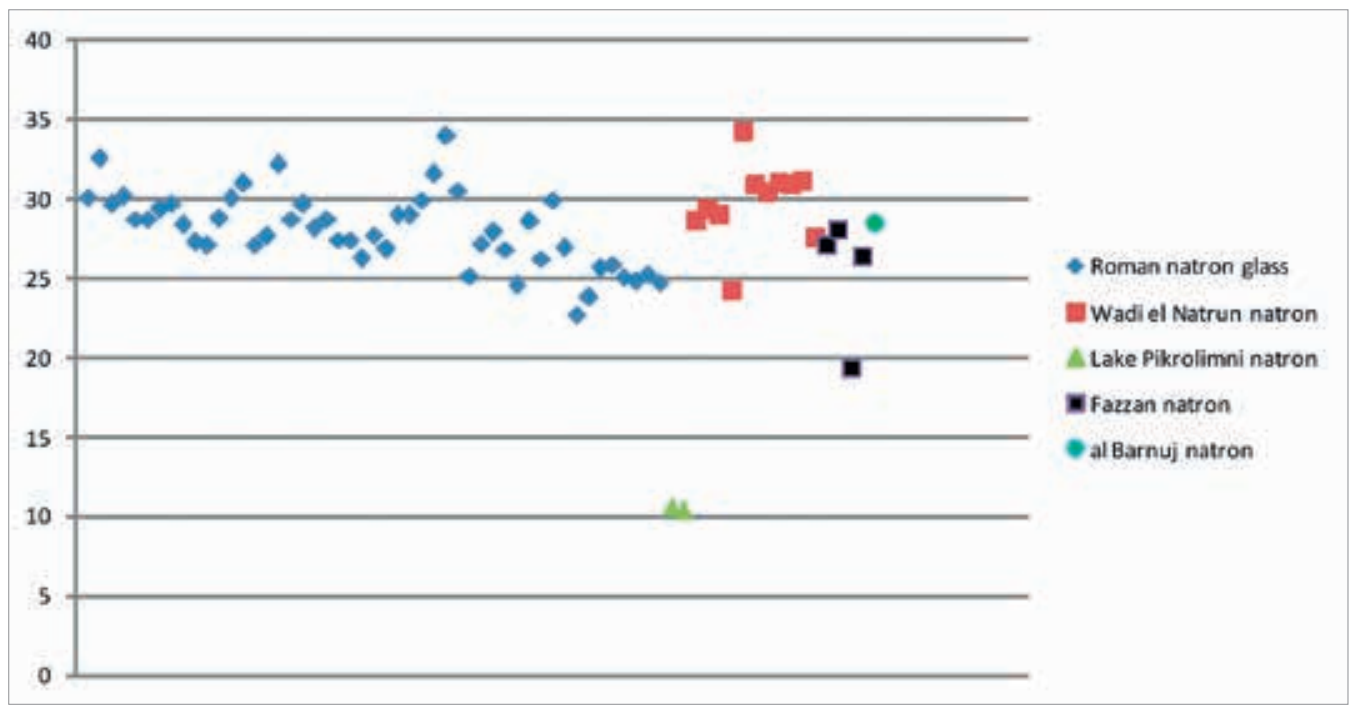


discovery of natron deposits in Libya shows that there may be many more such sources yet undiscovered in this part of the Roman world. All these North African sources cannot be distinguished from each other using boron isotopes, which is unsurprising in light of their very similar precipitation environment and geological background. Conversely, salts from Lake Pikrolimni in Greece are inconsistent with the B isotopic composition of ancient glass, and their use as a flux source in antiquity is highly unlikely. This makes placing the source of all flux for natron glassmaking in North Africa very tempting 5 . The occurrence and mining of natron throughout this part of the Roman world would make the supply of this raw material across the Mediterranean to primary factories in Italy or the western provinces much easier, even with overland transport.

Suitable glassmaking sands for Roman glass are rarer than would be generally thought. The use of chemical analysis makes it possible to distinguish between these different potential sources and reconstruct the primary origin of ancient natron glass. Northern Africa is the likely source of flux for all natron glassmaking. In the current state of research, other sources can be excluded as possible suppliers of flux for Roman glassmaking.

From our analyses, it is clear that glass factories in the eastern Mediterranean were active from the onset of natron glassmaking. The earliest natron glass with a likely non-eastern Mediterranean origin can be found in Carthage and is dated to the fourth century BC.

In early Roman times, between the first century $\mathrm{AD}$ and the first half of the fifth century $\mathrm{AD}$, the origin of primary natron glass lies in the western Mediterranean as well as in the eastern Mediterranean and possibly Italy. Apparently, investments were made in several glassmaking units all over the Empire. It is tempting to link this development in the glass industry to the end of the Roman Republic and the beginning of the Roman Empire, next to the impetus of the invention of glass-blowing. Most glass has a signature typical for a Syro-Palestinian or (possibly) an Italian provenance. Clear western Mediterranean or North African glass is only a minor part of the dataset. The large spread in neodymium isotopic composition of this Roman glass suggests primary production all over the Mediterranean, but it is also likely due to the intense recycling of this glass and mixing of several primary sources.

The signatures for an origin of glass in the western Mediterranean and presumably Italy slowly die out towards the end of the fifth century AD It is tempting to relate this process to the fall of the Western Roman Empire. As the mass production and export of goods declines or ceases in the course of the third to fourth century AD, the market and transport mechanisms for glass factories around the empire would have dissolved. In late Roman to early Byzantine/Islamic times, from the fifth century $\mathrm{AD}$ onwards, natron glassmaking once again becomes dependant on glass-producing sites in the eastern Mediterranean, both in Syro-Palestine and Egypt (with HIMT glass; NENNA, 2014).

It is clear that an improved dating resolution of the glass samples analyzed can help to better identify production units of natron glass in time and space. The discovery of a phasing in glassmaking in the Hellenistic-Roman world, however, adds a new chapter to the history of glass and our knowledge of the archaeological record. This new knowledge now needs to be integrated in further economic studies of the Roman world. 
We are grateful to Kris Latruwe, Steven Luypaers, Johan Honings and Elvira Vassilieva for help with sample preparation and chem$i c a l$ and isotopic analyses. The research is financially supported by the ERC Starting Grant ARCHGLASS (2009-2014), Grant agreement no. 240750 and FWO project no. 6.0864.09 (2009-2014).

\section{Notes}

1. The political situation in North Africa and the Middle East during the course of the project prohibited much fieldwork there, so the reference data available for these regions remains limited.

2. As data for possible sand sources from North Africa and other parts of the Mediterranean are still limited, the existence of competing Roman glass producers with overlapping elemental and isotopic characteristics in such areas cannot be definitively excluded. It is clear that our large scale geological prospecting needs a detailed archaeological follow-up if glass factories are to be discovered or confirmed.

3. Less than $2 \%$ of the dataset is glass with an origin likely in Egypt. Sampling HIMT glass, easily recognizable by its color, was avoided in this study, and the known Egypt I and II glass groups are rarely found outside of Egypt itself.

4. Slightly elevated concentrations in glass of trace elements commonly associated with coloring agents, such as $\mathrm{Mn}, \mathrm{Co}$, $\mathrm{Ni}, \mathrm{Cu}, \mathrm{Zn}, \mathrm{Sb}$ and $\mathrm{Pb}$, are often interpreted as the result of recycling of glass cullet. The analysis of these elements in suitable glassmaking sands provides a good idea of the background levels that can be attributed to impurities in the source of silica. The presence of higher amounts of these elements in Roman glass would indicate their deliberate or accidental (due to recycling of cullet) addition.

5. Since the B isotopic analysis of Roman glass and flux sources has just started, many aspects still need to be addressed. The analysis of ancient natron would be of great interest, especially to investigate whether present-day natron is characterized by a B isotopic signature similar to its ancient equivalent.

\section{Bibliography}

- Aerts et al., 2000: Ann Aerts, Koen Janssens, Bruce Velde, Freddy Adams, Helena Wouters, "Analysis of the Composition of Glass Objects from Qumrân, Israel," in NENNA, 2000, pp. 113-121.

- BAXTER, COOL, JACKSON, 2005: Michael Baxter, Hillary Cool, Caroline M. Jackson, "Further Studies in the Compositional Variability of Colourless Romano-British Vessel Glass," in Archaeometry, 47, 2005, pp. 47-68.

- BINGHAM, JACKSON, 2008: Paul A. Bingham, Caroline M. Jackson, "Roman blue-green bottle glass: chemical-optical analysis and high temperature viscosity modeling," in Journal of Archaeological Science, 35, 2008, pp. 302-309.

- Bostock, RiLey, 1857: John Bostock, Henry Thomas Riley, eds., The Natural History of Pliny, London, 1857.

- BRems, 2012 : Dieter Brems, Mineralogy and Geochemistry of Mediterranean Sand Deposits as a Raw Material for Roman Natron Glass Production, dissertation, KU Leuven, 2012.

- BREMS et al., 2012a: Dieter Brems, Patrick Degryse, Femke Hasendoncks, Domingo Gimeno, Alberta Silvestri, Elvira Vassilieva, Steven Luypaers, Johan Honings, "Western Mediterranean sand deposits as a raw material for Roman glass production," in Journal of Archaeological Science, 39/9, 2012, pp. 2835-2907. - BREMS et al., 2012b: Dieter Brems, Patrick Degryse, Monica Ganio, Sara Boyen, "The production of Roman glass with western Mediterranean sand raw materials: preliminary results," in European Journal of Glass Science and Technology, Part A Glass Technology, 53/4, 2012, pp. 129-138. - BREMs et al., 2013a: Dieter Brems, Monica Ganio, Kris Latruwe, Lieve Balcaen, Mike Carremans, Domingo Gimeno, Alberta Silvestri, Franck Vanhaecke, Philippe Muchez, Patrick Degryse, "Isotopes on the beach, Part 1: Strontium isotope ratios as a provenance indicator for lime raw materials used in Roman glassmaking," in Archaeometry, 55/2, 2013, pp. 214-234.

- BREMS et al., 2013b: Dieter Brems, Monica Ganio, Kris Latruwe, Lieve Balcaen, Mike Carremans, Domingo Gimeno, Alberta Silvestri, Frank Vanhaecke, Philippe Muchez, Patrick Degryse, "Isotopes on the beach, Part 2: Neodymium isotopic analysis for the provenancing of Roman glass-making," in Archaeometry, 55/3, 2013, pp. 449-464.
- BRILL, 1988: Robert H. Brill, "Scientific investigations of the Jalame glass and related finds," in Gladys Davidson Weinberg, ed., Excavations at Jalame: Site of a Glass Factory in Late Roman Palestine, Columbia, 1988, pp. 257-294.

- BRILl, 1999: Robert H. Brill, ed., Chemical Analyses of Early Glasses: I, Catalogue of Samples; II, Tables of Analyses, Corning, 1999.

- De Francesco et al., 2010: Anna M. De Francesco, Roberta Scarpelli, Donatella Barca, Annamaria Ciarallo, Luigi Buffone, "Preliminary chemical characterization of Roman glass from Pompeii," in Periodico di Mineralogia, 79, 2010, pp. 11-19.

- DEGRYSE, 2014: Patrick Degryse, ed. Glass Making in the Greco-Roman World: Results of the ARCHGLASS project, (Studies in Archaeological Sciences, 4), Leuven, 2014. - Degryse et al., 2006: Patrick Degryse, Jens Schneider, Udo Haack, Veerle Lauwers, Jeroen Poblome, Marc Waelkens, Philippe Muchez, "Evidence for glass 'recycling' using $\mathrm{Pb}$ and $\mathrm{Sr}$ isotopic ratios and Sr-mixing lines: the case of early Byzantine Sagalassos," in Journal of Archaeological Science, 33, 2006 , pp. 494-501.

- Degryse et al., 2010: Patrick Degryse, Andrew Shortland, David De Muynck, Lana Van Heghe, Rebecca Scott, Bert Neyt, Frank Vanhaecke, "Considerations on the provenance determination of plant ash glasses using strontium isotopes," in Journal of Archaeological Science, 37, 2010, pp. 3129-3135.

- Degryse, SchneIder, 2008: Patrick Degryse, Jens Schneider, "Pliny the Elder and Sr-Nd isotopes: tracing the provenance of raw materials for Roman glass production," in Journal of Archaeological Science, 35, 2008, pp. 1993-2000.

- Degryse, Shortland, 2009: Patrick Degryse, Andrew Shortland, "Trace Elements in Provenancing Raw Materials for Roman Glass Production," in Geologica Belgica, 12, 2009, pp. 135-143.

- DeVULDER et al., 2013: Veerle Devulder, Patrick Degryse, Frank Vanhaecke, "Development of a Novel Method for Unraveling the Origin of Natron Flux Used in Roman Glass Production Based on B Isotopic Analysis via Multicollector Inductively Coupled Plasma Mass Spectrometry," in Analytical Chemistry, 85/24, 2013, pp. 12077-12084.

- Devulder et al., 2014 : Veerle Devulder, Frank Vanhaecke, Andrew Shortland, David Mattingly, Caroline 
Jackson, Patrick Degryse, "Boron isotopic composition as a provenance indicator for the flux raw material in Roman natron glass," in Journal of Archaeological Science, 46, 2014, pp. 107-113.

- EichHolz, 1962: Pliny, translated by D. E. Eichholz, Natural History, X, Libri 36-37, (Loeb Classical Library, 419), Cambridge (MA), 1962.

- Fleming, SWANN, 1999: Stuart J. Fleming, Charles P. Swann, "Roman mosaic glass: a study of production processes, using PIXE spectrometry," in Nuclear Instruments and Methods in Physics Research Section B, 150, 1999, pp. 622-627.

- FOSTER, JACKSON, 2010: Harriet E. Foster, Caroline M. Jackson, "The composition of late Romano-British colourless vessel glass: glass production and consumption," in Journal of Archaeological Science, 37, 2010, pp. 3068-3080.

- Freestone, 2001: Ian C. Freestone, "Primary Glass Sources in the Mid First Millennium AD," in Annales du $15^{e}$ congrès de l'Association internationale pour l'histoire du verre : New York-Corning 2001, Nottingham, 2001, pp. 111-115.

- Freestone, 2005: Ian C. Freestone, "The Provenance of Ancient Glass through Compositional Analysis," in Materials Research Society Symposium Proceedings, 852, 2005, 008.1.1-008.1.14.

- Freestone, 2006: Ian C. Freestone, "Glass production in Late Antiquity and the Early Islamic period: a geochemical perspective," in Geomaterials in Cultural Heritage: Geological Society of London, Special Publications, 257, 2006, pp. 201-216.

- Freestone, 2008: Ian C. Freestone, "Pliny on Roman Glassmaking," in Marcos Martinón-Torres, Thilo Rehren, eds., Archaeology, History and Science: Integrating Approaches to Ancient Materials, Walnut Creek (CA), 2008, pp. 77-100.

- Freestone et al., 2000: Ian C. Freestone, Yael Gorin-Rosen, Michael J. Hughes, "Primary Glass from Israel and the Production of Glass in Late Antiquity and the Early Islamic Period," in NENNA, 2000, pp. 65-83.

- Freestone et al., 2002: Ian C. Freestone, Matthew Ponting, Michael J. Hughes, "The Origins of Byzantine Glass from Maroni Petrera, Cyprus," in Archaeometry, 44, 2002, pp. 257-272.

- Freestone et al., 2003: Ian C. Freestone, Karen A. Leslie, Matthew Thirlwall, Yael Gorin-Rosen, "Strontium Iso- topes in the Investigation of Early Glass Production: Byzantine and Early Islamic Glass from the Near East," in Archaeometry, 45, 2003, pp. 19-32.

- FREESTONE et al., 2008: Ian C. Freestone, Ruth E. Jackson-Tal, Oren Tal, "Raw Glass and the Production of Glass Vessels at Late Byzantine Apollonia-Arsuf, Israel," in Journal of Glass Studies, 50, 2008, pp. 67-80.

- FreEstone et al., forthcoming: Ian C. Freestone, Patrick Degryse, John Shepherd, Yael Gorin-Rosen, Jens Schneider, "Neodymium and Strontium Isotopes Indicate a Near Eastern Origin for Late Roman Glass in London," in Journal of Archaeological Science, forthcoming.

- GANIO et al., 2012a: Monica Ganio, Sara Boyen, Thomas Fenn, Rebecca Scott, Sofie Vanhoutte, Domingo Gimeno, Patrick Degryse, "Roman glass across the Empire: an elemental and isotopic characterization," in Journal of Analytical Atomic Spectrometry, 27/5, 2012, pp. 743-753.

- GANio et al., 2012b: Monica Ganio, Sara Boyen, Dieter Brems, Rebecca Scott, Danièle Foy, Kris Latruwe, Gianmario Molin, Alberta Silvestri, Frank Vanhaecke, Patrick Degryse, "Trade routes across the Mediterranean: a Sr/Nd isotopic investigation on Roman colourless glass," in European Journal of Glass Science and Technology Part A: Glass Technology, 53/5, 2012, pp. 217-224.

- Gibbins, 1991: David J. L. Gibbins, "The Roman wreck of c. AD 200 at Plemmirio, near Siracusa (Sicily): third interim report," in International Journal of Nautical Archaeology, 20, 1991, pp. 227-246.

- GORIN-ROSEN, 2000: Yael Gorin-Rosen, “The Ancient Glass Industry in Israel: Summary of the finds and new discoveries," in NENNA, 2000, pp. 49-63.

- GoRIN-Rosen, 2012: Yael Gorin-Rosen, "Remains of a Glass Inductry and Glass Finds from Horbat Biz'a," in Atiqot, 70 , pp. 49-62.

- HARding et al., 2004: Ian C. Harding, S. Trippier, James Steele, "The provenancing of flint artefacts using palynological techniques," in Elizabeth A. Walker, Francis Wenban-Smith, Frances Healy, eds., Lithics in Action: Papers from the Conference Lithic Studies in the Year 2000, Oxford, 2004, pp. 78-88.

- HARES, 1984: George B. Hares, "Composition and Constitution," in George W. McLellan, Errol B. Shand, eds., Glass Engineering Handbook, New York, 1984, pp. 1.3-1.11.
- Henderson, 1985: Julian Henderson, "The raw materials of early glass production," in Oxford Journal of Archaeology, 4, 1985, pp. 267-291.

- Henderson et al., 2005: Julian Henderson, Jane A. Evans, H. J. Sloane, M. J. Leng, Chris Doherty, "The use of oxygen, strontium and lead isotopes to provenance ancient glasses in the Middle East," in Journal of Archaeological Science, 32, 2005, pp. 665-673.

- HodGes, (1964) 1981: Henry Hodges, Artifacts: An Introduction to Early Materials and Technology, London, (1964) 1981.

- IXER, 2003: Rob A. Ixer, "Foundered or founded on rock - a future for Welsh Provenance Studies," in British Archeological Reports, 343, 2003, pp. 213-220.

- JACKSON, 2005: Caroline M. Jackson, "Making Colourless Glass in the Roman Period," in Archaeometry, 47, 2005. pp. 763-780.

- JACKSON, 2012: Caroline M. Jackson, "On the Provenance of Roman Glasses," in Ioannis Liritzis, Christopher M. Stevenson, eds., Obsidian and Ancient Manufactured Glasses, Albuquerque, 2012 , pp. 157-165.

- JACKSON et al., 2003: Caroline M. Jackson, Louise Joyner, Andrew Booth, Peter M. Day, Emma C. Wager, Vassilis Kilikoglou, "Roman Glass-Making at Coppergate, York? Analytical Evidence for the nature of Production," in Archaeometry, 45, 2003, pp. 435-456.

- JONES, 1963: Pliny, translated by W. H. S. Jones, Natural History, VIII, Libri 28-32, (Loeb Classical Library, 418), Cambridge (MA), 1963.

- JOSEPHUS, THACKERAY, 1927: Josephus, Henri St John Thackeray, Josephus, II, The Jewish War, Books 1-3, (Loeb Classical Library, 203), London/Cambridge (MA), 1927.

- Lierke, 2009: Rosemarie Lierke, Die nicht-geblasenen antiken Glasgefässe: ihre Herstellung von den Anfängen bis zu den Luxusglasern der Romer $=$ The Non-Blown Ancient Glass Vessels: Their Manufacturing from the Beginning to the Luxury Glasses of the Romans, Offenbach, 2009.

- NENNA, 2000: Marie-Dominique Nenna, ed., La Route du verre : ateliers primaires et secondaires du second millénaire av. J.-C. au Moyen Âge, (Travaux de la Maison de l'Orient, 33), Lyon, 2000, pp. 113-121. - Nenna, 2003: Marie-Dominique Nenna, “Les ateliers égyptiens à l'époque 
gréco-romaine," in Danièle Foy, ed., Coeur de verre : production et diffusion $d u$ verre antique, Gollion, pp. 32-33.

- NenNA, 2007: Marie-Dominique Nenna, “Production et commerce du verre à l'époque impériale : nouvelles découvertes et problématiques," in Facta, 1, pp. 125-147. - Nenna, 2014: Marie-Dominique Nenna, "Egyptian glass abroad: HIMT glass and its markets," in Daniel Keller, Jennifer Price, Caroline Jackson, eds., Neighbours and Successors of Rome: Traditions of Glass Production and Use in Europe and the Middle East in the Late First Millennium AD, Oxford, 2014, pp. 177-193.

- Nenna et al., 2000: Marie-Dominique Nenna, Maurice Picon, Michèle Vichy, "Ateliers Primaires et Secondaires en Égypte à l'Époque Gréco-Romaine," in NENNA, 2000, pp. 97-112.

- PAYNTER, 2006: Sarah Paynter, “Analyses of colourless Roman glass from Binchester, County Durham," in Journal of Archaeological Science, 33, 2006, pp. 1037-1057.

- Perkins, 1951: Ann Perkins, "Archaeological News," in American Journal of Archaeology, 55, 1951, pp. 81-100.

- PICON, VICHY, 2003: Maurice Picon, Michèle Vichy, “D'Orient en Occident: l'origine du verre à l'époque romaine et durant le haut Moyen Âge," in Danièle Foy, Marie-Dominique Nenna, eds., Échanges et commerce du verre dans le monde antique, (Monographies Instumentum, 24), Montagnac, pp. 17-31.

- Pillay, 2001: Avin E. Pillay, “Analysis of archaeological artefacts: PIXE, XRF or ICP-MS?" in Journal of Radioanalytical and Nuclear Chemistry, 247, 2001, pp. 593-595.

- Rosenow, ReHren, 2014: Daniela Rosenow, Thilo Rehren, "Herding cats - Roman to late Antique glass groups from Bubastis, northern Egypt," in Journal of Archaeological Science, 49, 2014, pp. 170-184.
- SAguí, 2007: Lucia Saguí, "Glass in Late Antiquity: The Continuity of Technology and Sources of Supply," in Luke Lavan, Enrico Zanini, Alexander Constantine Saranris, eds., Technology in Transition A.D. 300-650, Leiden/Boston, 2007, pp. 211-231.

- SAYRE, SMITH, 1961: Edward V. Sayre, Ray Winfield Smith, "Compositional Categories of Ancient Glass," in Science, 133 1961, pp. 1824-1826.

- Schibille, 2011 : Nadine Schibille, "Late Byzantine Mineral Soda High Alumina Glasses from Asia Minor: A New Primary Glass Production Group," in PLoS One, 6, 2011, pp. 1-13.

- SHELBY, (1997) 2005: James E. Shelby, Introduction to Glass Science and Technology, Cambridge, (1997) 2005.

- Shortland et al., 2006: Andrew Shortland, Lucas Schachner, Ian C. Freestone, Michael Tite, "Natron as a flux in the early vitreous materials industry: sources, beginnings and reasons for decline," in Journal of Archaeological Science, 33, 2006, pp. 521-530.

- Shortland et al., 2007: Andrew Shortland, Nick Rogers, Katherine Eremin, "Trace element discriminants between Egyptian and Mesopotamian Late Bronze Age glasses," in Journal of Archaeological Science, 34, 2007 , pp. 781-789.

- SILVESTRI, 2008: Alberta Silvestri, "The coloured glass of Iulia Felix," in Journal of Archaeological Science, 35, 2008, pp. 1489-1501. - SiLVESTRI et al., 2006: Alberta Silvestri, Gianmario Molin, Gabriella Salviulo, R. Schievenin, "Sand for Roman Glass Production: An Experimental and Philological Study on Source of Supply," in Archaeometry, 48, 2006, pp. 415-432.

- STERn, 1999: E. Marianne Stern, “Roman Glassblowing in a Cultural Context," in American Journal of Archaeology, 103, 1999, pp. 441-484.
- STERN, 2002: E. Marianne Stern, “Glass is Hot," in American Journal of Archaeology, 106, 2002, pp. 463-471.

- STEvenson, 1914: Cornelius Stevenson, "Bowl of Roman Madrepore Glass," in Bulletin of the Pennsylvania Museum, 12, 1914, pp. 25-27.

- StRABO, Jones, 1932: Strabo, Horace Leonard Jones, The Geography of Strabo, VIII, (Loeb Classical Library, 267), Cambridge (MA), 1932.

- TAL et al., 2004: Oren Tal, Ruth E. Jackson-Tal, Ian C. Freestone, “New evidence of the production of raw glass at Late Byzantine Apollonia-Arsuf, Israel," in Journal of Glass Studies, 2004, 46, pp. 51-66.

- Thorley, 1969: John Thorley, "The Development of Trade between the Roman Empire and the East under Augustus," in Greece o Rome, 16/2, 1969, pp. 209-223.

- Wedepohl, BAumanN, 2000: Karl Hans Wedepohl, Albrecht Baumann, "The Use of Marine Molluskan Shells for Roman Glass and Local Raw Glass Production in the Eifel Area (Western Germany)," in Naturwissenschaften, 87, 2000, pp. 129-132.

- Wedepohl et al., 2011: Karl Hans Wedepohl, Klaus Simon, Andreas Kronz, "Data on 61 Chemical Elements for the Characterization of Three Major Glass Compositions in Late Antiquity and the Middle Ages," in Archaeometry, 53, 2011 , pp. 81-102.

- West, 1932: Louis C. West, "The Economic Collapse of the Roman Empire," in The Classical Journal, 28, 1932, pp. 96-106. - Wilson, POlLARD, 2001: Lyn Wilson, A. Mark Pollard, "The provenance hypothesis," in Don R. Brothwell, A. Mark Pollard, eds., Handbook of Archaeological Sciences, Chichester, 2001, pp. 507-517. 